\title{
The Effects of Slicing Parameters on Surface Qualify of European Beech Wood
}

\section{Utjecaj parametara rezanja na kvalitetu površine bukovine}

\author{
Original scientific paper • Izvorni znanstveni rad \\ Received-prispjelo: 2. 3. 2020. \\ Accepted-prihvaćeno: 14. 1. 2021. \\ UDK: $630 * 832.281 .6 ; 674 * 031.12$ \\ https://doi.org/10.5552/drvind.2021.2013
}
(C) 2021 by the author(s). Licensee Faculty of Forestry, University of Zagreb. This article is an open access article distributed under the terms and conditions of the Creative Commons Attribution (CC BY 4.0) license.

\begin{abstract}
The main objective of this work was to evaluate the effects of flat slicing processes on wood surface characteristics of the European beech (Fagus sylvatica L.). The relation between wettability, roughness and machining methods were studied. Two different wood thickness (3.4 and $4.0 \mathrm{~mm}$ ) and three levels of compression during slicing $(67.5 \%, 57.5 \%$ and $47.5 \%$ of desired veneer thickness) were used to prepare surfaces prior to testing. The smaller variation of the thickness of thinner veneers was observed. No significant impact of compression on variation of the thickness was found. The contact angle was lower when roughness measured parallel to the grain was higher. The influence of selected compression on roughness of European beech veneers measured perpendicular to the grain was confirmed. This indicated that the influence of the set of machining processes, such as pressure bar setting during slicing, is significant for wooden veneers surface properties.
\end{abstract}

Keywords: contact angles; wood wettability; European beech; slicing; pressure bar set

SAŽETAK • Glavni cilj rada bio je procijeniti učinke plošnog rezanja furnira na svojstva površine bukovine (Fagus sylvatica L.). Proučavan je odnos između kvašenja i hrapavosti bukovine i metoda rezanja furnira. Za pripremu površine za ispitivanja upotrijebljene su dvije različite debljine furnira $(3,4$ i 4,0 mm) i tri razine kompresije tijekom rezanja furnira $(67,5,57,5$ i 47,5\% željene debljine furnira). Uočena su manja odstupanja debljine tanjih furnira. Nije utvrđen značajan utjecaj kompresije na varijacije debljine furnira. Kontaktni kut bio je manji kada je hrapavost paralelno s vlakancima drva bila veća. Potvrđen je utjecaj odabranog pritiska na hrapavost bukova furnira okomito na vlakanca drva. To je pokazalo da postavke procesa obrade, primjerice odabir pritiska tijekom rezanja, znatno utječu na svojstva površine furnira.

Ključne riječi: kontaktni kut; kvašenje drva; bukovina; rezanje; postavke pritiska

\section{INTRODUCTION \\ 1. UVOD}

According to the European Federation of the Parquet Industry, Poland is the leader in the production of flooring materials in Europe, reaching almost $17 \%$ of the European production, which gives approx. 29.5 million $\mathrm{m}^{2}$ of flooring produced each year. Most of manufactured floor materials are layered floorboards (EPLF/GFA, 2020). The significance of proper management of raw materials leads to savings and reducing of production costs and forced modification of current-

${ }^{1}$ Authors are researchers at Warsaw University of Life Sciences, Institute of Wood Sciences and Furniture, Warsaw, Poland. 
ly used machining methods and development of new solutions, such as replacing flat-sawing by more efficient (chipless) technology like slicing. A well-planned production process can provide more proficient production by reducing the amount of waste. It is already known that slicing (or peeling) conditions clearly affect the process energy and forces as well as the quality of wood surface (Aguilera and Zamora, 2009; Aguilera and Muñoz, 2011; Thoma et al., 2015). Thus, the effects of different surfacing methods are of great interest in order to improve the preparation of materials. In every industrial production process, the occurrence of faults in processing is unavoidable. However, in the context of technological requirements, if the quality deviations are within certain limit values, then the detail is considered to have been properly processed. However, it occurs that the dimensions of the detail are within the limit values, and the problem lies in the quality of the machined surface. This is partly due to the fact that mechanical treatments change the chemical and morphological characteristics of wood surfaces (Liptákova and Kúdela, 1994), with the types of machining along with the characteristics of the raw material, or a combination of both these parameters, determining the surface quality and influencing the cost (Kilic et al., 2006; Mitchell and Lemaster, 2002).

In addition to the physical, mechanical, as well as the anatomical properties of wood, the surface quality of finished products is influenced by numerous factors such as: the direction of slicing, geometry of the blade and its sharpness, thickness of the cut part, any sharpening faults, as well as the technological parameters (speed of slicing, speed of movement, pressure bar settings, etc.) (Richter et al., 1995; Hernández and Cool, 2008; Haouzali et al., 2019). Surface properties are usually monitored in order to assess the quality of machining processes (Hernández and Cool, 2008). The surface roughness affects the wetting characteristics of materials, and the increase of surface roughness is associated with an increase of surface wettability. Surface roughness of veneer plays an important role in plywood manufacturing. Because of its effect on gluing and bonding characteristics, veneer surface roughness is an important factor in the production of glued timber products such as LVL (Dündar et al., 2008). Moreover, desired surface roughness is strongly and directly linked to or influenced by the future use condition, making it crucial in flooring production, especially in case of glue laminated floorboards. An effective control of surface roughness is important in production processes related to the adhesive bonding of wood elements and the final processing of finished products (Lemaster et al., 1982; Keturakis, 2007; Arnold, 2010; Thoma et al., 2015). Relatively little research has been made concerning the effects of machining on the wetting characteristics of wood surfaces. Wood of deciduous porous structure has been tested more often (Gindl et al., 2001; Qin et al., 2014; Ugulino and Hernandez, 2015).

Beech, next to birch and oak, is the most abundant deciduous species in Europe (Boratyńska and Boratyński 1990). The total area of beech dominated forest in Europe is estimated to cover ca 14-15 Mha (excluding the Caucasian mountains) with the largest areas in France, central and southern Germany, and the southeast European mountains (Carpathians, Dinaric and Balkan mountains) (Hahn and Fanta, 2001; Standovár and Kenderes, 2003). In Poland only, the stock of thick beech wood is about 90 million $\mathrm{m}^{3}$. It is estimated that the market share of beech wood will systematically increase due to the observed expansion of this species (Tarasiuk, 1999; Dobrowolska, 2011). European beech is an expansive, fast-growing tree species gradually expanding its area of occurrence, whose wood can be an alternative to the dominant European oak in flooring.

The main objective of this work was to evaluate the effects of slicing processes on wood surface characteristics of the European beech (Fagus sylvatica L.). The relations between wettability, roughness and slicing parameters were studied. Two different wood thicknesses and three levels of compression were used during slicing to prepare surfaces prior to testing of selected characteristics.

\section{MATERIALS AND METHODS 2. MATERIJALI I METODE}

Typical European beech (Fagus sylvatica L.) was selected as a test species, because of its wide application in the European wood industry for the production of floors, both from solid wood and glue laminated wood. Sawn wood of diameters of $20.5 \mathrm{~cm} \times 12.0 \mathrm{~cm}$ $\times 100.0 \mathrm{~cm}($ tangential $\times$ radial $\times$ longitude $)$ was used. Material derived from Polish forest managed by the State Forests National Forest Holding. Beams were graded into two groups for flat slicing thickness of about 3.4 and $4.0 \mathrm{~mm}$.

The beech wood beams were hydrothermally treated before slicing. The treatment process included: $5 \mathrm{~h}$ of heating up to the temperature of $60^{\circ} \mathrm{C}, 42 \mathrm{~h}$ of thermo-hydro treatment at a temperature of $90{ }^{\circ} \mathrm{C}$ and $1 \mathrm{~h}$ of cooling down to a temperature of $60^{\circ} \mathrm{C}$. The flat slicing process was carried out on a FEZER Lumber Slicer FM 30 adapted for this purpose. The wood was sliced flat with variable compression of $67.5 \%, 57.5 \%$ and $47.5 \%$ of desired veneer thickness. Slicing speed was set at $100 \mathrm{~m} / \mathrm{min}$. Drying was carried out in a Vanicek 25 dryer. After drying, moisture content of wood was approx. $8.0 \%$.

The thickness variation of the obtained European beech veneers was determined using an optical microscope (SMZ 1500, Nikon) with image analysing software. The same microscope was used to prepare images of analysed veneer surfaces.

The contact angles of expanding droplets, i.e. advancing angles, were determined using a contact angle measuring device and using the Owens-Wendt methods (Owens and Wendt, 1969) with Petrič and Oven recommendations (Petrič and Oven, 2015) on a Goniometer Haas Phoenix 300 contact angle analyser connected to imaging software. The image analysis system calculated the contour of the drop from an image cap- 
..... Jankowska, Kozakiewicz, Zbieć: The Effects of Slicing Parameters on Surface Quality...

Table 1 Levels of tested factors in relation to European beech veneer wettability and roughness

Tablica 1. Vrijednosti ispitivanih čimbenika s obzirom na kvašenje i hrapavost bukovine

\begin{tabular}{|c|c|c|c|}
\hline $\begin{array}{c}\text { Veneer thickness, } \mathrm{mm} \\
\text { Debljina furnira, } \mathrm{mm}\end{array}$ & $\begin{array}{c}\text { Veneer side } \\
\text { Strana furnira }\end{array}$ & $\begin{array}{c}\text { Compression, \% of the thickness } \\
\text { Kompresija, postotak debljine }\end{array}$ & $\begin{array}{c}\text { Measurement direction } \\
\text { Smjer mjerenja }\end{array}$ \\
\hline \multirow{3}{*}{3.4} & tight / zatvorena & 67.5 & $\begin{array}{c}\text { perpendicular to the grain }(\perp) \\
\text { okomito na vlakanca drva }(\perp)\end{array}$ \\
& loose / otvorena & 57.5 & $\begin{array}{c}\text { parallel to the grain (II) } \\
\text { paralelno s vlakancima drva (II) }\end{array}$ \\
\hline
\end{tabular}

tured using a video camera. The contact angle was calculated as the average of both sides of the droplets, to compensate for any horizontality variations. The initial contact angles recorded immediately after droplet deposition were used to estimate the wood surface energies using Berthelot's combining rule (Kwok and Neumann, 2000). The measurements were repeated 30 times. Distilled water was used for testing.

Roughness of the veneers was evaluated in accordance with the requirements of ISO 4287 (1997). As a part of the conducted research, the arithmetic mean deviation of the assessed profile $\left(R_{\mathrm{a}}\right)$ was measured. The surface roughness was tested using the Surftest SJ-210 Series 178-Portable Surface Roughness Tester (Mitutoyo Corporation). The parameter $R_{\mathrm{a}}$ was measured 30 times each in parallel and perpendicular to the grain direction for each tested variant. The analysis of wood roughness as well as wood surface wettability were done on the tight ("right") and loose ("left") side of the European beech veneers.

A statistical analysis of the test results was carried out using Statistica v. 10 software (StatSoft Inc.). The data were analysed and provided as the mean \pm standard deviation. To determine the relations between the tested wood properties, simple regressions were used. Analysis of variance (ANOVA) was also made at the 0.05 level of significance. The test factors and their variability levels are given in Table 1.

\section{RESULTS AND DISCUSSION}

\section{REZULTATI I RASPRAVA}

\subsection{Variation in thickness}

3.1. Varijacije debljine

The obtained veneers were characterised by a relatively small variation in the thickness (Figure 1).
The coefficient of variation (defined as the ratio of the standard deviation to the mean) was $1.8 \%$ (mean value) for $3.4 \mathrm{~mm}$ thick veneers and $2.3 \%$ (mean value) for $4.0 \mathrm{~mm}$ thick veneers. These values were in $5 \%$ industrial range recommendation (Feihl, 1986) and so the slicing quality was good. A slight variation of the thickness of thinner veneers was most probably caused by lower tensions in material as slicing thin veneer generates lower cutting forces (Haouzali et al., 2019). Previous experiments (Rahayu, 2016) indicated that it is more difficult to maintain thickness regularity for thinner veneers. On the other hand, a study conducted on Fagus sylvatica L. wood (Daoui, 2011) confirmed our conclusion. Probably, an observation of the inverse relation resulted from the use of relatively high material compression during cutting. It allowed to reduce tensions and made dimensions more stable. The regression analysis made for each veneer thicknesses did not confirm the significance of compression values.

\subsection{Wettability and roughness of European beach veneers \\ 3.2. Kvašenje i hrapavost bukova furnira}

The results of measurements of contact angles as well as the results of measurements of roughness parallel and perpendicular to the grain are shown in Table 2. For the wood surfaces in case of each veneer thickness obtained with different compression, contact angle was in the range of $79.7^{\circ}$ to $99.8^{\circ}$ for tight side and $85.8^{\circ}$ to $93.7^{\circ}$ for loose side. There was no significant difference in contact angle measurements on those sides.

The different machining process did not affect surface wettability, as determined by contact measurements. The ANOVA did not confirm significant dependence between veneer thickness, veneer side or use of different compression values (Table 3 ). It was ob-

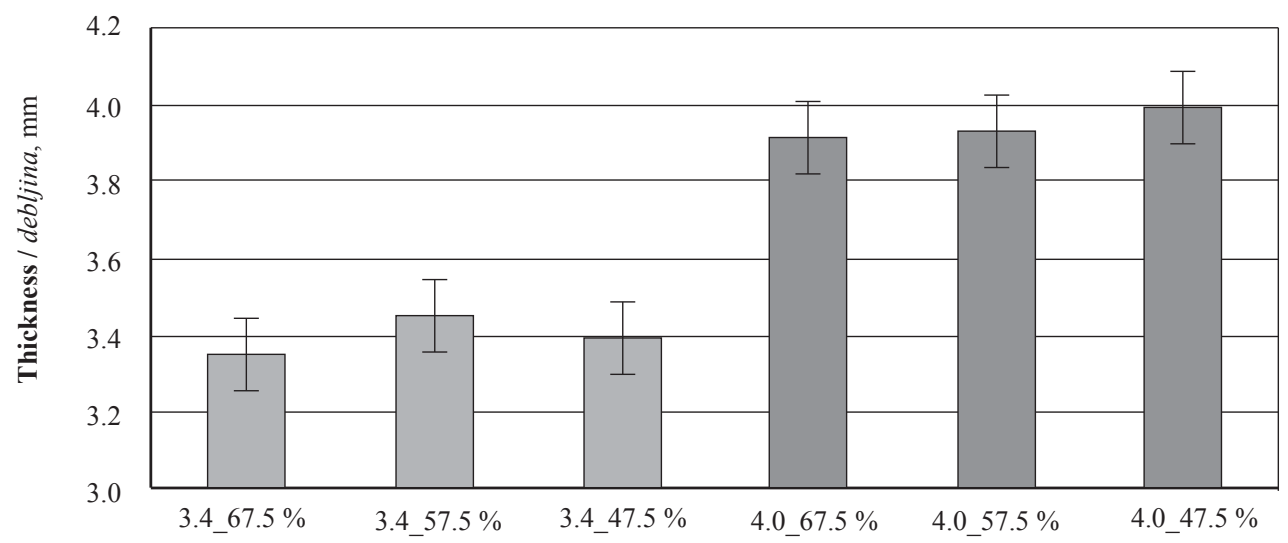

Figure 1 Variation in European beech veneer with a nominal thickness of $3.4 \mathrm{~mm}$ and $4.0 \mathrm{~mm}$

Slika 1. Varijacije bukova furnira nominalne debljine 3,4 i $4 \mathrm{~mm}$ 
Table 2 Contact angles, roughness parallel to the grain and perpendicular to the grain of tested European beech veneers (in parentheses standard deviations are given)

Tablica 2. Kontaktni kutovi, hrapavost paralelno s vlakancima drva i hrapavost okomito na vlakanca drva ispitivanih bukovih furnira (u zagradama su standardne devijacije)

\begin{tabular}{|c|c|c|c|c|c|}
\hline $\begin{array}{l}\text { Side } \\
\text { Strana }\end{array}$ & $\begin{array}{c}\text { Thickness, } \mathbf{m m} \\
\text { Debljina, } \mathrm{mm}\end{array}$ & $\begin{array}{l}\text { Compression, \% of thickness } \\
\text { Kompresija, postotak debljine }\end{array}$ & $\begin{array}{c}\text { Roughness } \perp, \mu \mathrm{m} \\
\text { Hrapavost } \perp, \mu \mathrm{m}\end{array}$ & $\begin{array}{c}\text { Roughness } \|, \mu \mathrm{m} \\
\text { Hrapavost } \|, \mu \mathrm{m}\end{array}$ & $\begin{array}{l}\text { Wettability, }^{\circ} \\
\text { Kvašenje, }^{\circ}\end{array}$ \\
\hline \multirow{6}{*}{$\begin{array}{l}\text { Tight } \\
\text { zatvorena }\end{array}$} & \multirow{3}{*}{3.4} & 67.5 & $7.85(1.37)$ & $4.68(1.45)$ & $99.8(2.6)$ \\
\hline & & 57.5 & $8.98(1.12)$ & $4.81(2.81)$ & $95.5(5.7)$ \\
\hline & & 47.5 & $9.60(2.05)$ & $4.95(2.41)$ & $82.4(3.8)$ \\
\hline & \multirow{3}{*}{4.0} & 67.5 & $8.19(1.96)$ & $4.84(2.24)$ & $88.8(8.5)$ \\
\hline & & 57.5 & $8.82(1.15)$ & $4.73(1.04)$ & $87.8(5.4)$ \\
\hline & & 47.5 & $9.16(1.67)$ & $5.10(1.23)$ & $79.9(6.1)$ \\
\hline \multirow{6}{*}{$\begin{array}{l}\text { Loose } \\
\text { otvorena }\end{array}$} & \multirow{3}{*}{3.4} & 67.5 & $13.29(3.01)$ & $6.45(0.90)$ & $87.7(5.8)$ \\
\hline & & 57.5 & $12.47(2.65)$ & $7.78(1.77)$ & $93.7(4.0)$ \\
\hline & & 47.5 & $11.58(2.62)$ & $7.47(2.06)$ & $90.8(1.1)$ \\
\hline & \multirow{3}{*}{4.0} & 67.5 & $13.45(2.33)$ & $7.00(1.16)$ & $85.8(9.0)$ \\
\hline & & 57.5 & $11.19(1.44)$ & $7.59(2.94)$ & $87.2(5.6)$ \\
\hline & & 47.5 & $11.66(1.79)$ & $5.76(1.51)$ & $89.3(4.3)$ \\
\hline
\end{tabular}

Table 3 Results of ANOVA for wettability, roughness parallel to the grain and perpendicular to the grain

Tablica 3. Rezultati ANOVA analize vrijednosti kvašenja, hrapavosti paralelno s vlakancima drva i hrapavosti okomito na vlakanca drva

\begin{tabular}{|c|c|c|c|c|c|c|}
\hline \multirow[t]{2}{*}{$\begin{array}{l}\text { Feature } \\
\text { Svojstvo }\end{array}$} & \multirow[t]{2}{*}{$\begin{array}{l}\text { Factor } \\
\text { Čimbenik }\end{array}$} & $\begin{array}{c}\text { Sum of squares } \\
\text { Zbroj kvadrata }\end{array}$ & $\begin{array}{c}\text { Degrees of } \\
\text { freedom } \\
\text { Stupnjevi } \\
\text { slobode }\end{array}$ & $\begin{array}{c}\text { Mean sum } \\
\text { of squares } \\
\text { Srednji zbroj } \\
\text { kvadrata }\end{array}$ & $\begin{array}{l}\text { Fisher's F-test } \\
\text { Fisherov F-test }\end{array}$ & $\begin{array}{c}\text { Significance } \\
\text { level } \\
\text { Razina } \\
\text { značajnosti }\end{array}$ \\
\hline & & $S S$ & $D F$ & $M S$ & $F$ & $p$ \\
\hline \multirow{3}{*}{$\begin{array}{l}\text { Wettability } \\
\text { kvašenje }\end{array}$} & Side / strana & 0.000 & 1 & 0.0000 & 0.000 & 0.989304 NS \\
\hline & Thickness / debljina & 80.701 & 1 & 80.701 & 3.245 & $0.114673^{\mathrm{NS}}$ \\
\hline & Compression / kompresija & 72.771 & 2 & 36.392 & 1.463 & $0.294580^{\mathrm{NS}}$ \\
\hline \multirow{3}{*}{$\begin{array}{l}\text { Roughness } \perp \\
\text { hrapavost } \perp\end{array}$} & Side / strana & 36.867 & 1 & 36.867 & 41.563 & $0.000351 *$ \\
\hline & Thickness / debljina & 0.144 & 1 & 0.144 & 0.163 & $0.698875^{\mathrm{NS}}$ \\
\hline & Compression / kompresija & 0.219 & 2 & 0.109 & 0.123 & $0.885925^{\mathrm{NS}}$ \\
\hline \multirow{3}{*}{$\begin{array}{l}\text { Roughness II } \\
\text { hrapavost II }\end{array}$} & Side / strana & 13.944 & 1 & 13.944 & 39.478 & $0.000411^{*}$ \\
\hline & Thickness / debljina & 0.102 & 1 & 0.102 & 0.290 & $0.606905^{\mathrm{NS}}$ \\
\hline & Compression / kompresija & 0.545 & 2 & 0.273 & 0.772 & $0.497982^{\mathrm{NS}}$ \\
\hline
\end{tabular}

$\mathrm{NS}$ - not significant, * - significant at the 0.05 level / NS - nije značajno, * -značajno na razini 0,05

Table 4 Results of simple regression analysis for wettability, roughness parallel to the grain and perpendicular to the grain depending on compression

Tablica 4. Rezultati jednostavne regresijske analize za kvašenje, hrapavost paralelno s vlakancima drva i hrapavost okomito na vlakanca drva u ovisnosti o kompresiji

\begin{tabular}{|c|c|c|c|c|c|c|c|}
\hline \multirow[t]{2}{*}{$\begin{array}{c}\text { Side } \\
\text { Strana }\end{array}$} & \multirow[t]{2}{*}{$\begin{array}{l}\text { Feature } \\
\text { Svojstvo }\end{array}$} & $\begin{array}{c}\text { Coefficient of } \\
\text { correlation } \\
\text { Koeficijent } \\
\text { korelacije }\end{array}$ & $\begin{array}{c}\text { Sum of } \\
\text { squares } \\
\text { Zbroj } \\
\text { kvadrata }\end{array}$ & $\begin{array}{l}\text { Mean sum of } \\
\text { squares } \\
\text { Srednji zbroj } \\
\text { kvadrata }\end{array}$ & $\begin{array}{c}\begin{array}{c}\text { Degrees of } \\
\text { freedom }\end{array} \\
\text { Stupnjevi } \\
\text { slobode } \\
\end{array}$ & $\begin{array}{l}\text { Fisher's } \\
\text { F-test } \\
\text { Fisherov } \\
\text { F-test } \\
\end{array}$ & $\begin{array}{c}\text { Significance } \\
\text { level } \\
\text { Razina } \\
\text { značajnosti } \\
\end{array}$ \\
\hline & & $R$ & $S S$ & $M S$ & $D F$ & $F$ & $p$ \\
\hline \multirow{3}{*}{$\begin{array}{c}\text { Tight } \\
\text { zatvorena }\end{array}$} & $\begin{array}{l}\text { Wettability } \\
\text { kvašenje }\end{array}$ & 0.776 & 173.054 & 173.054 & 4 & 6.075 & $0.069340^{\mathrm{NS}}$ \\
\hline & $\begin{array}{c}\text { Roughness } \perp \\
\text { hrapavost } \perp\end{array}$ & 0.945 & 1.856 & 1.856 & 4 & 33.630 & $0.004397 *$ \\
\hline & $\begin{array}{c}\text { Roughness II } \\
\text { hrapavost II }\end{array}$ & 0.781 & 0.072 & 0.072 & 4 & 6.255 & $0.066696^{\mathrm{NS}}$ \\
\hline \multirow{3}{*}{$\begin{array}{c}\text { Loose } \\
\text { otvorena }\end{array}$} & $\begin{array}{l}\text { Wettability } \\
\text { kvašenje }\end{array}$ & 0.517 & 10.857 & 10.857 & 4 & 1.461 & $0.293387^{\mathrm{NS}}$ \\
\hline & $\begin{array}{c}\text { Roughness } \perp \\
\text { hrapavost } \perp\end{array}$ & 0.826 & 3.062 & 3.062 & 4 & 8.542 & $0.043125^{*}$ \\
\hline & $\begin{array}{l}\text { Roughness II } \\
\text { hrapavost II }\end{array}$ & 0.061 & 0.011 & 0.011 & 4 & 0.015 & $0.908011^{\mathrm{NS}}$ \\
\hline
\end{tabular}

NS - not significant, * - significant at the 0.05 level / NS - nije značajno, *-značajno na razini 0,05 


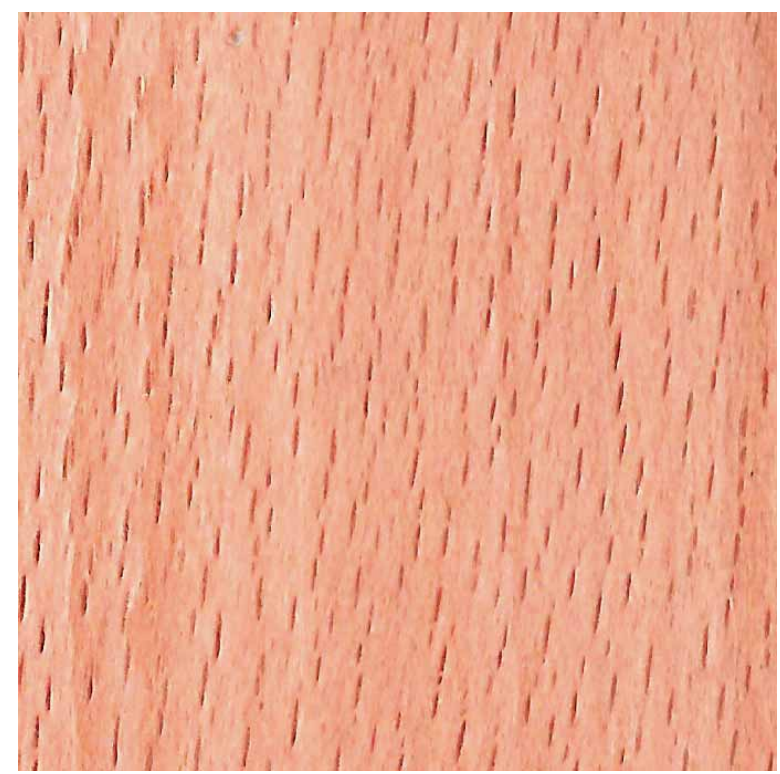

a

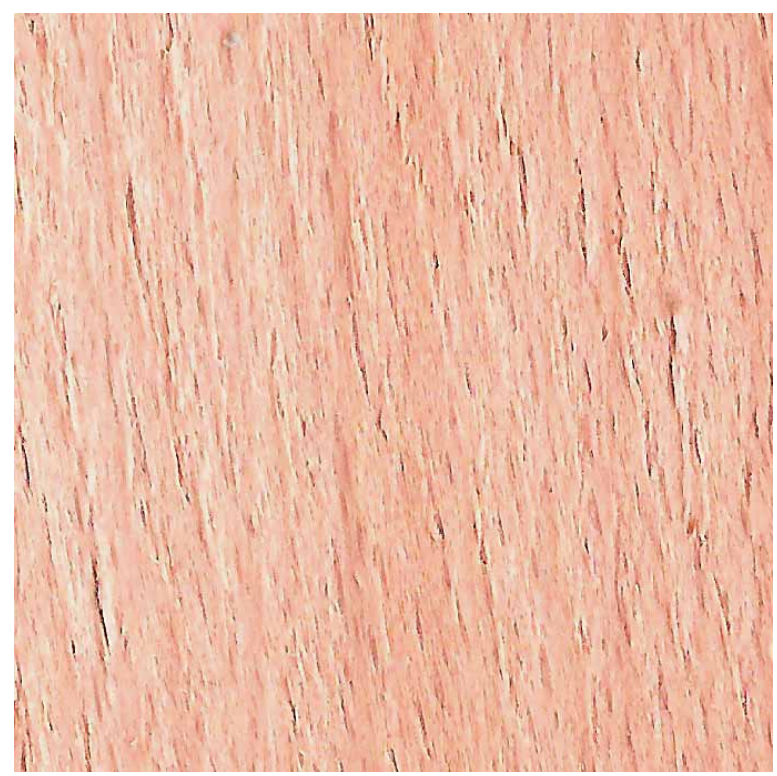

b

Figure 2 Macrographs of tight side (a) and loose side (b) of tested veneers - magnification 4x Slika 2. Izgled zatvorene (a) i otvorene (b) strane ispitivanih furnira - povećanje 4 puta

served that the higher compression during slicing, the higher is the contact angle with water. Simple regression analysis confirmed the influence of selected compression values on roughness of European beech veneers in both parallel and perpendicular to the grain directions (Table 4). Wood roughness was higher when the compression was lower. This indicates that the influence of the set of machining parameters, such as slicing, is visible in the surface quality. The same conclusion was made by de Moura and Hernández (2007), who tested sugar maple wood surfaces machined with the fixed-oblique knife pressure-bar cutting system.

The wood surface roughness is an important characteristic in terms of surface quality and properties, particularly in the case of finishing treatments (Buyuksari et al., 2011). Veneer with a rough surface can also cause excessive resin use and may result in resin bleeding through the face veneer (Dündar et al., 2008). The roughness of tested veneers varied significantly depending on the measurement direction (parallel and perpendicular to the grain) and veneer side. The roughness values measured perpendicular to the grain were twice as high as those measured parallel to the grain. ANOVA confirmed significance of veneer side on roughness values (Table 3 ). The loose side was characterised by a greater roughness because more irregularities and cracks appeared on that side due to tensile stresses. Such stresses are an effect of veneer bending during the peeling process. According to previous studies (Candan et al., 2010; Bekhta et al., 2012), the improvement of surface quality of veneers is very important for bonding quality in bonded wood panels. Reducing the roughness, mainly on the loose side, reduces stress points between the wood surface and the adhesive, increasing the shear strength of the glue line (Rahayu, 2016).

Wood is not a homogeneous material, and its properties vary in different directions as a result of its anatomical structure (Li et al., 2018). The measurement perpendicular to the grain contains irregularities that are mainly caused by the size of the structural wood elements. In the case of deciduous wood species, these ele-

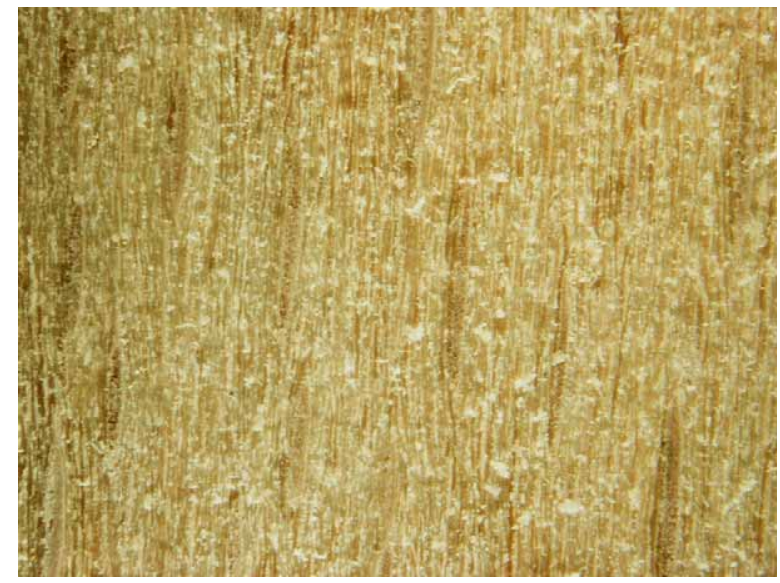

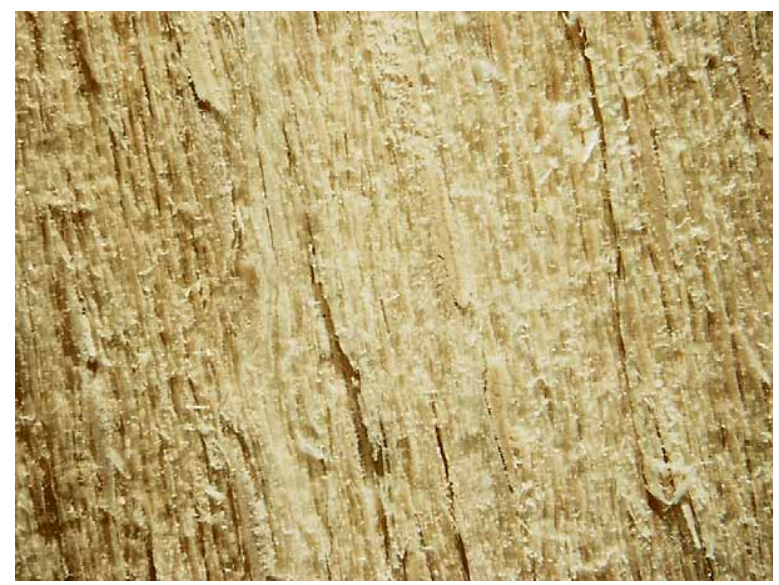

b

Figure 3 Micrographs of tight side (a) and loose side (b) of tested veneers - magnification 20x

Slika 3. Mikrografije zatvorene (a) i otvorene (b) strane ispitivanih furnira - povećanje 20 puta 
ments are primarily fibres and vessels. The observed differences were due to the difference in texture in perpendicular and longitudinal direction of European beech wood. Moreover, wood quality depends on surface morphology (Jankowska et al., 2019). In case of tight side of veneers, only a few cell wall fibrillations roughed the surface. Microscopic images revealed that on loose side the wood fibres and other cellular elements were torn out, mechanically destroyed and even crushed. In addition, loos side of veneers exhibited several cracks and some delamination (Figure 2 and 3).

Simple regression analysis was carried out to verify the existence of a relation between surface roughness measured perpendicular and parallel to the grain and wood wettability. According to results, the correlation between these properties was poor in case of roughness measured parallel to the grain (coefficient of correlation $\mathrm{R}_{\wedge}=0.719$ was not significant) and in case of roughness measured parallel to the grain $R_{c c}=0.851$ was significant. On the other hand, based on our results, it can be concluded that the contact angle is lower when roughness (value of $R_{a}$ parameter) is higher and that, consequently, wood wettability is also higher. The same inference was made by Arnold (2010), who tested differently machined solid wood surfaces regarding surface properties and coating performance.

\section{CONCLUSIONS \\ 4. ZAKLJUČAK}

Based on the results of the research conducted, it can be concluded that compression is significant for the surfaces of wood such as European beech slicing. Using pressure bar set (relatively high material compression) during wood slicing allowed to reduce internal stresses providing dimensions to be more stable. The smaller variation of the thickness was observed in thinner veneers. The contact angle was lower when roughness was higher, thus wood wettability was higher. The influence of selected compression factors on roughness of European beech veneers perpendicular to the grain was confirmed. This indicates that the influence of the machining parameters of processes such as slicing is significant for the surface properties of wooden veneers. This type of innovation has the potential to be used, among others, in the furniture industry and the production of wooden layered floors.

\section{Acknowledgements - Zahvala}

The presented research was made in the project: „Increasing the efficiency of using wood raw material in production processes in industry". This project was co-financed by the National Centre for Research and Development (NCBR) under Strategic Research and Development Programme "Environment, Agriculture and Forestry" - BIOSTRATEG, Project No. BIOSTRATEG2/298950/1/NCBR/2016.

\section{REFERENCES}

\section{LITERATURA}

1. Aguilera, A.; Muñoz, H., 2011: Rugosidad superficial y potencia de corte en el cepillado de Acacia melanoxylon y Sequoia sempervirens. Maderas: Ciencia y Tecnologia, 13 (1): $19-28$

http:// 10.4067/S0718-221X2011000100002.

2. Aguilera, A.; Zamora, R., 2009: Surface roughness in sapwood and heartwood of Blackwood (Acacia melanoxylon R. Br.) machined in 90-0 direction. European Journal of Wood Products, 67: 297-301. http://dx.doi.org/10.1007/s00107-009-0308-2.

3. Arnold, M., 2010: Planing and sanding of wood surfaces - Effects on surface properties and coating performance. In: Proceedings of PRA's $7^{\text {th }}$ International Woodcoatings Congress; Middlesex: Hampton.

4. Bekhta, P.; Niemz, P.; Sedliacik, J., 2012: Effect of prepressing of veneer on the glueability and properties of veneer-based products. European Journal of Wood and Wood Products, 70: 99-106. http://dx.doi.org/10.1007/s00107-010-0486-y.

5. Buyuksari, U.; Akbulut, T.; Guler, C.; As, N., 2011: Wettability and surface roughness of natural and plantationgrown narrow-leaved (Fraxinus angustifolia Vahl.) wood. BioResources, 6: 4721-4730. http://dx.doi.org/10.15376/biores.6.4.4721-4730.

6. Boratyńska, K.; Boratyński A., 1990: Systematyka i geograficzne rozmieszczenie. In: Białobok S. (red.), Buk zwyczajny Fagus sylvatica L. Nasze drzewa leśne. Monografie popularnonaukowe. Tom 10. PWN, Warszawa, Poznań, pp. 27-73.

7. Candan, Z.; Hiziroglu, S.; McDonald, A. G., 2010: Surface quality of thermally compressed Douglas fir veneer. Materials \& Design, 31: 3574-3577. http://dx.doi.org/10.1016/j.matdes.2010.02.003.

8. Daoui, A.; Descamps, C.; Marchal, R.; Zerizer, A., 2011: Influence of veneer quality on beech lvl mechanical properties. Maderas: Ciencia y tecnología, 13 (1): 69-83. http://dx.doi.org/10.4067/S0718-221X2011000100007.

9. de Moura, L. F.; Hernández, R. E., 2007: Characteristics of sugar maple wood surfaces machined with the fixedoblique knife pressure-bar cutting system. Wood Science and Technology, 41 (1): 17-29. http://dx.doi.org/10.1007/s00226-006-0074-9.

10. Dobrowolska, D., 2011: Zasięg buka w Polsce a zmiany klimatu. Las Polski 2011, 17: 24.

11. Dündar, T.; Ayrilmis, N.; Candan, Z., 2008. Evaluation of surface roughness of laminated veneer lumber (LVL) made from beech veneers treated with various fire retardants and dried at different temperatures. Forest Products Journal, 58 (1/2): 71-76.

12. Feihl, O., 1986: Veneer cutting manual. Forintek Canada Corp, Special publication SP 510.

13. Gindl, M.; Sinn, G.; Reiterer, A.; Tschegg, S., 2001: Wood surface energy and time dependence of wettability: A comparison of different wood surfaces using an acid-base approach. Holzforschung, 55: 433-440.

14. Hahn, K.; Fanta, J., 2001: Contemporary beech forest management in Europe. NAT-MAN Working Report 1.

15. Haouzali, H.; Marchal, R.; Bléron, L.; Butaud, J. C., 2019: Peeling of poplar: cultivars and forest stations effect on veneer quality. Journal of Materials and Environmental Science, 10 (3): 244-253.

16. Hernández, R. E.; Cool, J., 2008: Effects of cutting parameters on surface quality of paper birch wood machined across the grain with two planing techniques. Holz als Roh- und Werkstoff, 66 (2): 147-154. http://dx.doi.org/10.1007/s00107-007-0222-4.

17. Jankowska, A.; Zbieć, M.; Kozakiewicz, P.; Koczan, G.; Oleńska, S., Beer, P., 2018: The wettability and surface free energy of sawn, sliced and sanded European oak 
wood. Maderas: Ciencia y tecnología, 20 (3): 443-454. http://dx.doi.org/10.1007/s13213-011-0384-5.

18. Keturakis, G.; Juodeikienè, I., 2007: Investigation of milled wood surface roughness. Materials Science (Medžiagotyra) 13 (1): 47-51.

19. Kilic, M.; Hiziroglu, S.; Burdurlu, E., 2006: Effect of machining on surface roughness of wood. Building and Environment, 41: 1074-1078. http://dx.doi.org/10.1016/j.buildenv.2005.05.008.

20. Kwok, D. Y.; Neumann, A. W., 2000: Contact angle measurements and contact angle interpretation: relevance to the thermodynamics of adhesion. In: Acid-base interactions: relevance to adhesion science and technology, vol. II. Utrecht, Holland, pp. 91-166.

21. Lemaster, R.; Dornfeld, D., 1982: Measurement of surface quality of sawn and planed surfaces with a laser. In $7^{\text {th }}$ Wood Machining Seminar. October 18-20, University of California, Forest Products Laboratory, Richmond, CA, pp. 54-61.

22. Li, G.; Wu, Q.; He, Y.; Liu, Z., 2018: Surface roughness of thin wood veneers sliced from laminated green wood lumber. Maderas: Ciencia y tecnología, 20 (1): 3-10. http://dx.doi.org/10.4067/s0718-221x2018005001101.

23. Liptáková, E.; Kúdela, J., 1994: Analysis of the woodwetting process. Holzforschung, 48 (2): 139-144. http://dx.doi.org/10.1515/hfsg.1994.48.2.139.

24. Mitchell, P.; Lemaster, R., 2002: Investigation of machine parameters on the surface quality in routing soft maple. Forest Products Journal, 52 (6): 85-90.

25. Owens, D. K; Wendt, R. C., 1969: Estimation of the surface free energy of polymers. Journal of Applied Polymer Science, 13 (8): 1741-1747. http://dx.doi.org/10.1002/ app.1969.070130815.

26. Petrič, B.; Oven, P., 2015: Determination of wettability of wood and its significance in wood science and technology: a critical review. Reviews of Adhesion and Adhesives, 3 (2): 121-187. http://dx.doi.org/10.7569/RAA.2015.097304.

27. Qin, Z.; Gao, Q.; Zhang, S.; Li, J., 2014: Surface free energy and dynamic wettability of differently machined poplar woods. BioResources, 9 (2): 3088-3103. http://dx.doi.org/10.15376/biores.9.2.3088-3103.
28. Rahayu-Sekartiing, I., 2016: Characteristics of lathe check and surface roughness of fast growing wood veneers and their performance on laminated veneer lumber, $\mathrm{PhD}$ thesis. ENSAM Cluny, France.

29. Richter, K.; Feist, W.; Kanebe, M., 1995: The effects of surface roughness on the performance of finishes. Forest Products Journal, 45 (7/8): 91-97.

30. Standovár, T.; Kenderes, K., 2003: A review on natural stand dynamics in beechwoods of east central Europe. Applied Ecology and Environmental Research, 1: 19-46. http://dx.doi.org/10.15666/aeer/01019046.

31. Tarasiuk, S., 1999: Buk zwyczajny (Fagus sylvatica L.) na obrzeżach zasięgu w Polsce: warunki wzrostu i problemy hodowlane. Fundacja Rozwój SGGW, Warszawa.

32. Thoma, H.; Peri, L.; Lato, E., 2015: Evaluation of wood surface roughness depending on species characteristics. Maderas: Ciencia y tecnología, 17 (2): 285-292. http://dx.doi.org/10.4067/S0718-221X2015005000027.

33. Ugulino, B.; Hernández, R. E., 2015: Effects of four surfacing methods on surface properties and coating performance of red oak wood. In: Proceedings of the $22^{\text {nd }}$ International Wood Machining Seminar, June 14-17, Quebec City, Canada.

34. ***EPLF/GFA, 2020: EPLF reports stabilisation in 2019. http://parquet.net/ (Accessed Jul. 20, 2020).

35. ***ISO 4287, 1997: Geometrical product specifications (GPS) - Surface texture: Profile method - Terms, definitions and surface texture parameters. International Organization for Standardization, Geneva, Switzerland.

\section{Corresponding address:}

\section{AGNIESZKA JANKOWSKA, Ph.D. D.Sc.}

Warsaw University of Life Sciences Institute of Wood Sciences and Furniture Nowoursynowska 159 St., 02-776 Warsaw, POLAND e-mail: agnieszka_jankowska@sggw.pl 